\title{
Hurthle cell carcinoma of the thyroid
}

\author{
Mark Anthony S Sandoval, Elizabeth Paz-Pacheco \\ Section of Endocrinology, Diabetes and Metabolism, Department of Medicine, Philippine General Hospital, University of the Philippines, Manila, Philippines
}

Correspondence to Mark Anthony S Sandoval, markanthony_sandoval@yahoo.com

\begin{abstract}
Summary
A 63-year-old man consulted for a non-toxic thyroid nodule of 2 years' duration. Fine needle aspiration revealed cell findings consistent with papillary thyroid carcinoma. He eventually underwent total thyroidectomy. Microscopic examination revealed histologic features of Hurthle cell carcinoma of the thyroid. He received radioactive iodine therapy and suppressive levothyroxine treatment. Post-therapy whole body iodine-131 scan revealed thyroid tissue remnants limited to the anterior neck. Four months after radioactive iodine therapy, thyroglobulin level is low and the patient remains to have no evidence of disease.
\end{abstract}

\section{BACKGROUND}

Hurthle cells, also called oncocytes, are cells that undergo morphologic changes in response to cellular stress. These cells can be found in the thyroid and in other organs. These may proliferate and give rise to nodules, both benign and malignant. A case of Hurthle cell carcinoma of the thyroid gland is presented here. This is an uncommon type of differentiated thyroid carcinoma with a distinct microscopic appearance. Following is a review of literature regarding its nature, prevalence and management.

\section{CASE PRESENTATION}

A 63-year-old man presented with a 2-year history of goitre. He did not experience weight loss, palpitations, tremors and heat intolerance. He denies having dysphagia, dyspnoea and hoarseness. Aside from a prior hospitalisation 20 years ago for abdominal pain, he has no other known illnesses. He has not been subjected to irradiation of the neck. None of his relatives had goitre. He does not smoke and neither does he consume alcohol.

Heart rate was 66 per min, respiratory rate 16 per min and blood pressure $140 / 90 \mathrm{~mm} \mathrm{Hg}$. The left thyroid lobe was enlarged to $8 \times 7 \mathrm{~cm}$ and was form in consistency. There were no palpable neck nodes. There were no eye changes and tremors. The rest of the physical examination findings were unremarkable.

Clinical impression was a non-toxic single thyroid nodule (International Classification of Diseases -10 code E04.1) and suspect hypertension.

\section{INVESTIGATIONS}

Free thyroxine was slightly low at $9.9 \mathrm{pmol} / \mathrm{l}$ (normal: 11-24 pmol/l) while thyroid stimulating hormone (TSH) was normal at $0.9 \mu \mathrm{IU} / \mathrm{ml}$ (normal: $0.3-3.8 \mu \mathrm{IU} / \mathrm{ml}$ ).

Thyroid ultrasound showed that the left lobe was converted into a large lobulated multinodular mass measuring $9.8 \times 7.6 \times 5.5 \mathrm{~cm}$. There was peripheral vascularity on color flow study. No calcifications were seen and no cervical lymphadenopathy was appreciated. The right thyroid lobe measured $4.5 \times 2.8 \times 2.3 \mathrm{~cm}$ with a heterogeneous echo pattern. The vascular pattern on color flow was also increased. There was a $0.4 \mathrm{~cm}$ cystic focus at the inferior pole and a hypoechoic $0.7 \mathrm{~cm}$ hypoechoic focus at the middle portion. The latter also had increased internal vascularity on color flow.

Fine needle aspiration biopsy of the left thyroid revealed cells with large nuclei that were elongated, grooved and had intranuclear inclusions. These cell findings are consistent with papillary thyroid carcinoma. The cytoplasm appeared orange in colour, a feature of oncocytic change (figure 1).

Total thyroidectomy was performed. A mass $9 \mathrm{~cm}$ in greatest dimension was seen in the left lobe. Histologic examination using $\mathrm{H} \& \mathrm{E}$ staining showed a nodule predominantly composed of cells arranged in cords with individual cells having abundant granular, eosinophilic cytoplasm and 'cherry pink' nucleoli (figures 2 and 3). There are tumour cells seen invading adjacent vascular structures (figure 4). There was also capsular invasion (figure 5).

\section{DIFFERENTIAL DIAGNOSIS}

These findings were interpreted as Hurthle cell carcinoma of the thyroid. Postoperative staging was T3N0M0 age $>45$ years (stage II). Adenomatous nodules were also seen in the right lobe and isthmus.

\section{TREATMENT}

The patient eventually received radioactive iodine-131 therapy at a dose of $100 \mathrm{mCi}(3700 \mathrm{MBq})$. Post-therapy whole body iodine-131 scan revealed thyroid tissue remnants limited to the anterior neck. He was started on suppressive doses of levothyroxine at $2.2 \mathrm{mcg} / \mathrm{kg} /$ day.

\section{OUTCOME AND FOLLOW-UP}

Four months after radioactive iodine therapy and after withdrawing levothyroxine for 4 weeks, there is already no evidence of disease. Thyroglobulin was low at $0.1 \mathrm{ng} /$ $\mathrm{ml}$ at TSH level of $>100 \mu \mathrm{IU} / \mathrm{ml}$. Antithyroglobulin antibody was undetectable. Levothyroxine was resumed for TSH suppression 


\section{BMJ Case Reports}

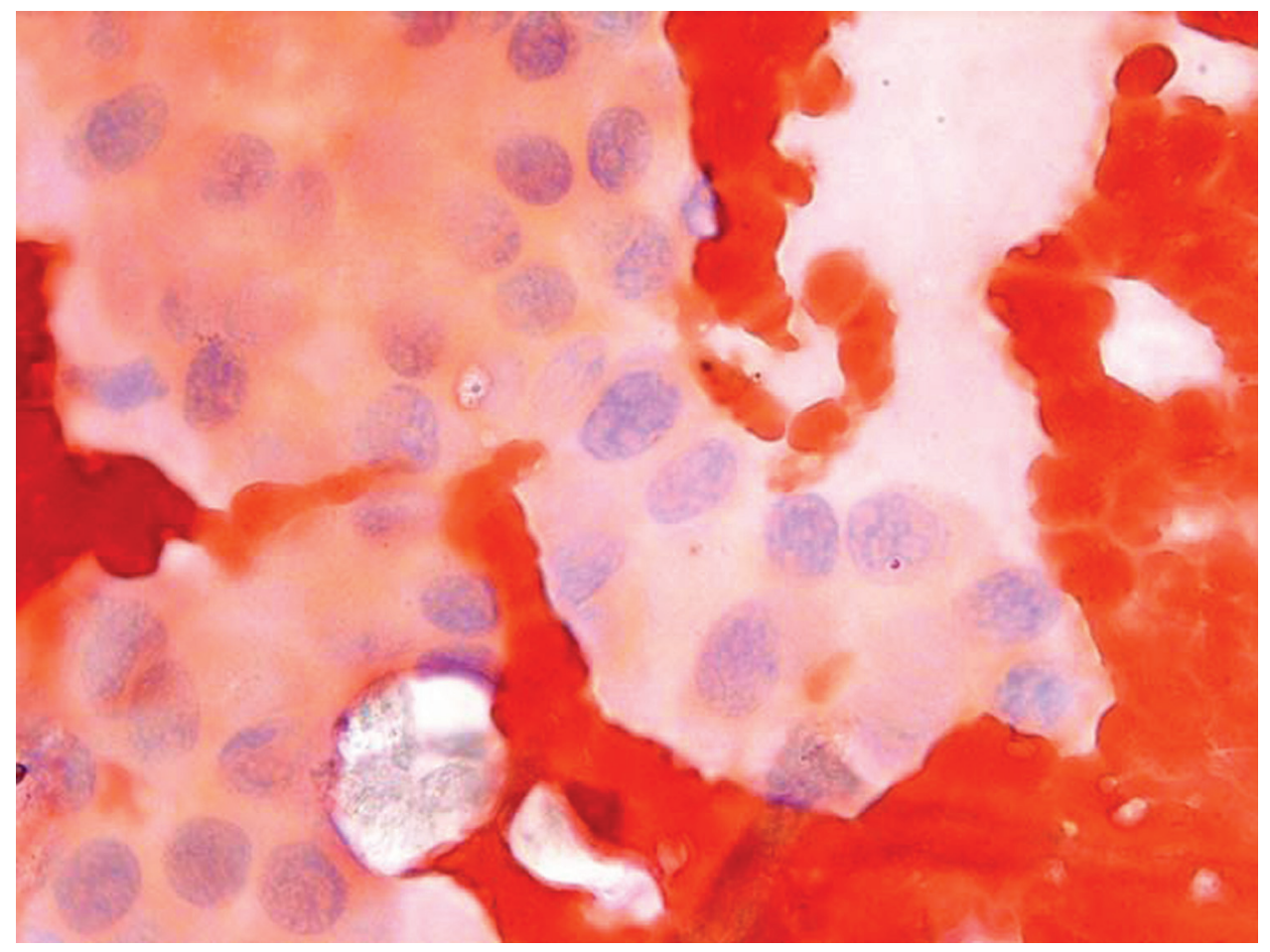

Figure 1 Fine needle aspiration biopsy showing cells with nuclei that were large, elongated, had grooves and intranuclear inclusions. These are findings consistent with papillary thyroid carcinoma.

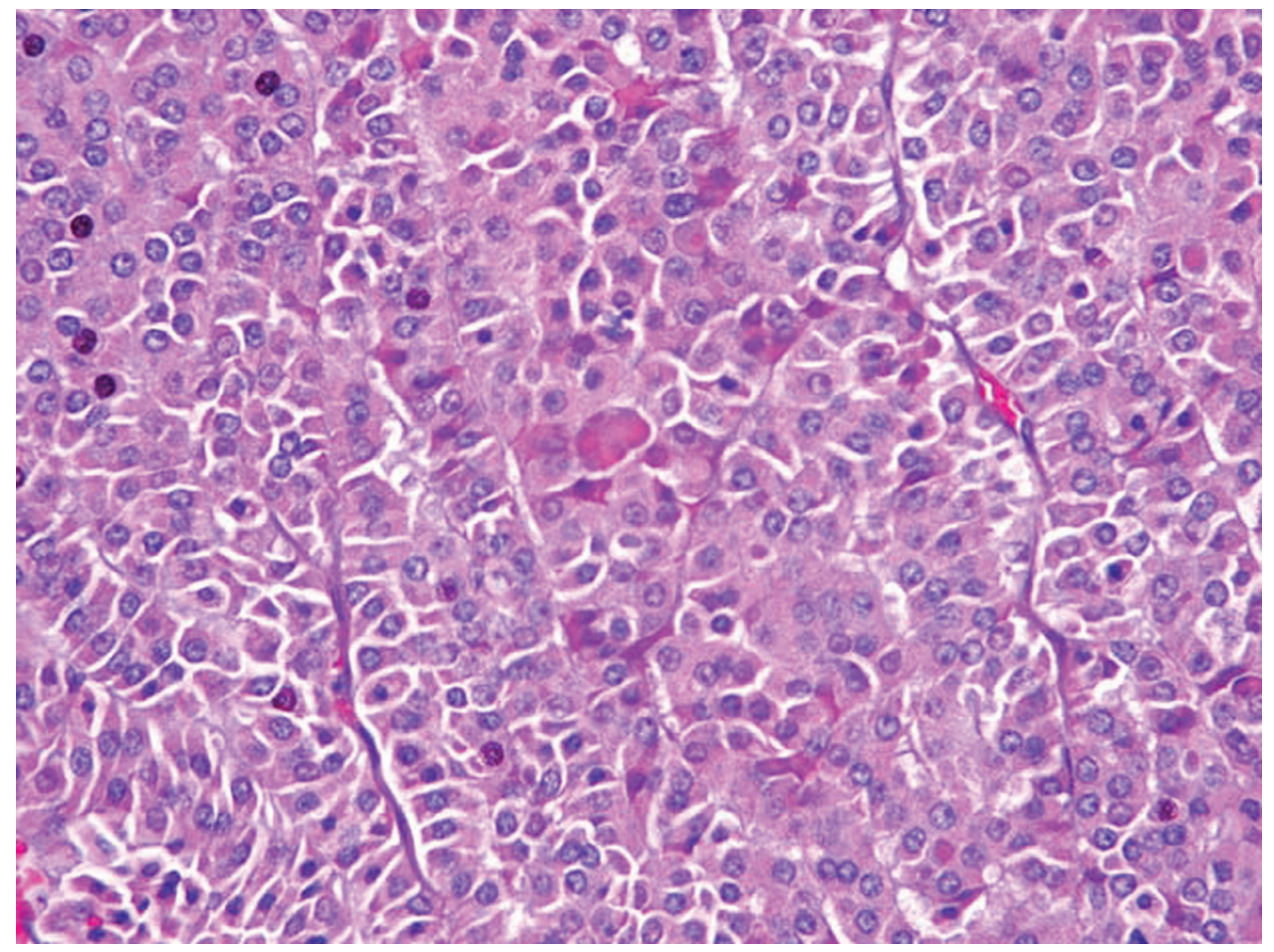

Figure 2 Photomicrograph showing the polygonal tumour cells with abundant eosinophilic granular cytoplasm ( $\times 400$ magnification).

\section{DISCUSSION}

\section{What is a 'Hurthle cell?'}

So-called Hurthle cells are cells that have undergone oncocytic change. Oncocytic change pertains to the cellular change characterised by an abundant eosinophilic granular cytoplasm due to the accumulation of altered mitochondria. ${ }^{1}$ This change occurs in inflammatory diseases and when a cell is subjected to similar stress. ${ }^{2}$ In the thyroid, these cells are found in irradiated thyroids, ageing thyroids, nodular goitre, chronic lymphocytic thyroiditis and long- 


\section{BMJ Case Reports}

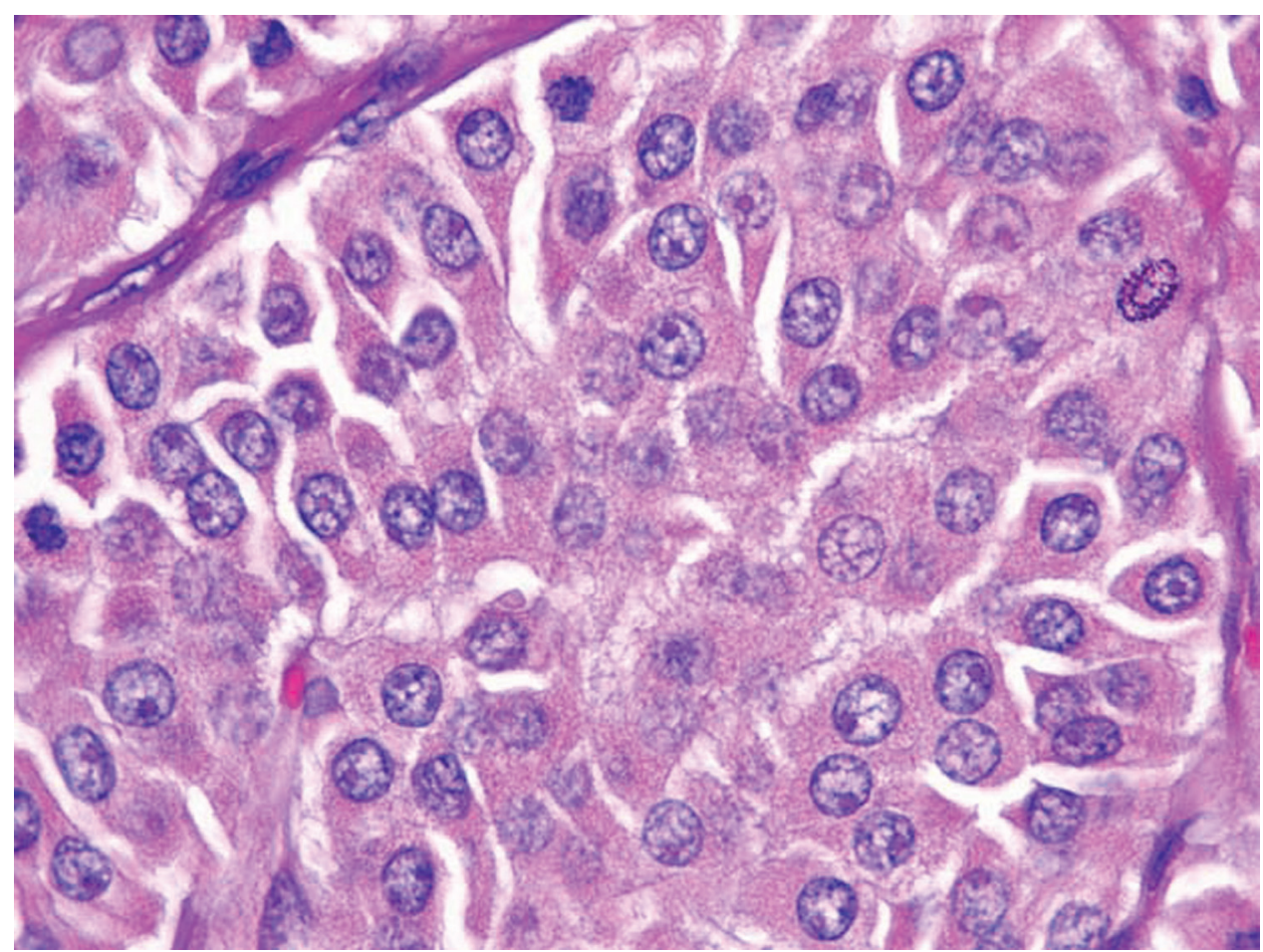

Figure 3 Photomicrograph showing the eosinophilic granular cytoplasm of individual cells. Note the cherry pink appearance of the nucleoli ( $\times 1000$ magnification).

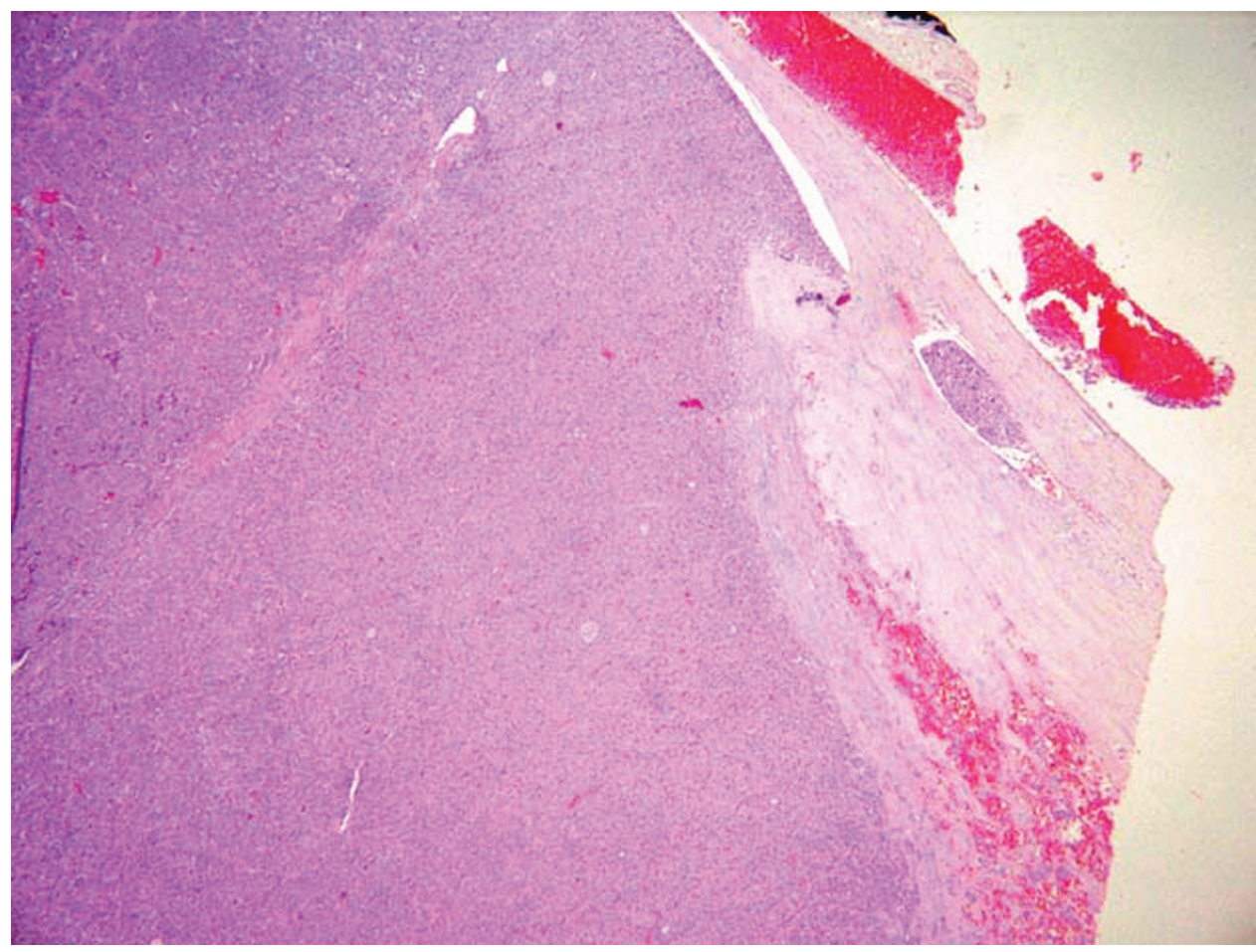

Figure 4 Photomicrograph showing on the right the presence of tumour cells within a vein, indicative of vascular invasion $(\times 40$ magnification).

standing Graves' disease. Oncocytic change can occur in any type of cell and Hurthle cells are not exclusively seen in the thyroid gland. They may also be seen in the parathyroids, pituitary, adrenal cortex, pancreas, gut, lungs, parotid gland and kidneys. ${ }^{1}$
It is actually wrong to ascribe the Hurthle cell to the German histologist Karl W Hurthle because what he described initially were the parafollicular or C cells. It was Askenazy who initially described these oncocytic cells. ${ }^{1}$ 


\section{BMJ Case Reports}

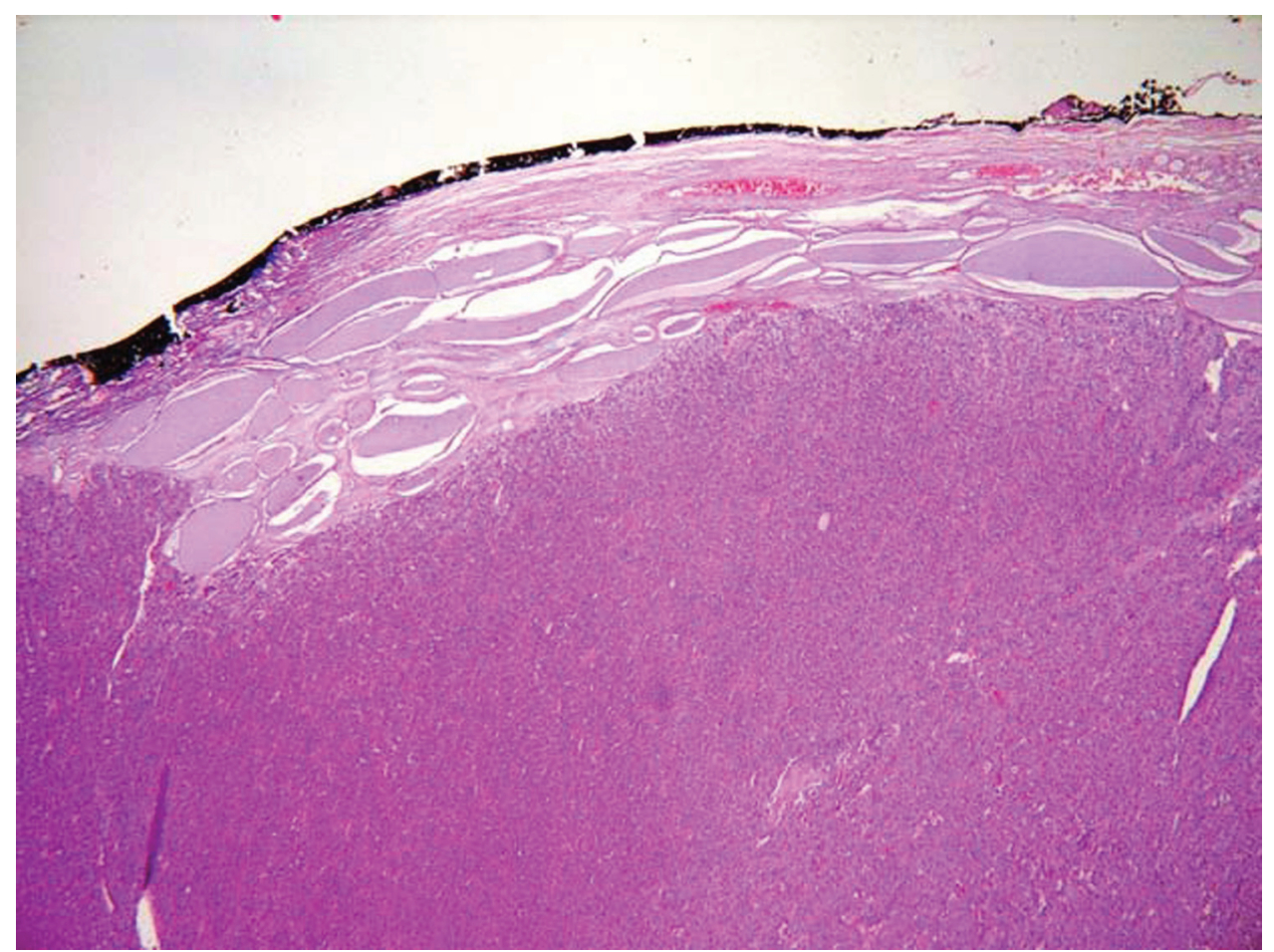

Figure 5 Photomicrograph showing capsular invasion by the tumour on the left portion ( $\times 40$ magnification).

Cellular features on light microscopy using H\&E staining include large size, polygonal to square, distinct cell borders, voluminous granular and eosinophilic cytoplasm, large hyperchromatic nucleus and cherry pink nucleoli. ${ }^{1}$

Electron microscopy reveals a granular cytoplasm due to large mitochondria filling the cell. ${ }^{3} 4$

\section{What are the histologic features of Hurthle cell neoplasms?}

Proliferation of Hurthle cells can lead to hyperplastic or neoplastic nodules. Hurthle cell nodules are so-called if $>75 \%$ of a lesion is composed of this cell type. ${ }^{5}$ The criterion for follicular tumours is applied in determining whether a Hurthle cell nodule is benign or malignant. Thus, the presence of capsular or vascular invasion suggests malignancy (carcinoma) while their absence suggests otherwise (adenoma). While Hurthle cell carcinoma is regarded as a subtype of follicular carcinoma, there is an entity called Hurthle cell papillary carcinoma. Tumours are labelled as such when cytologic criteria for papillary carcinoma are present (nuclei are enlarged, elongated, irregular in shape, crowded, overlapping, with prominent grooves and inclusions; clearing of nucleoplasm and peripheral margination of chromatin) together with the oncocytic change. ${ }^{5}$

Aside from capsular and vascular invasion, malignancy may be deduced if the tumour exhibits positivity for HBME-1, CK-19 and Ret/PTC gene rearrangements. ${ }^{5}$ Expression by Hurthle cell neoplasms of the proliferation index Ki-67 is also associated with aggressive histologic findings (vascular invasion, capsular invasion and extrathyroidal extension). ${ }^{6}$

Hurthle cell carcinoma is considered a follicular thyroid neoplasm for various reasons: (1) numerous transition forms have been demonstrated between follicular and
Hurthle cells in the same gland, (2) Hurthle cells in the thyroid express thyroglobulin but not thyrocalcitonin and (3) TSH can stimulate adenylate cyclase in certain Hurthle cell neoplasms. The WHO classifies Hurthle cell carcinoma of the thyroid as follicular carcinoma, oxyphilic cell type. ${ }^{1}$

However, it has been found that Hurthle cell carcinomas and follicular carcinomas express various oncogenes in different ways. A greater proportion of Hurthle cell carcinomas express Pan-ras, N-myc, TGF- $\alpha$, TGF- $\beta$ and IGF-1 compared with follicular carcinomas. ${ }^{7}$ This article thus implies that follicular carcinoma and Hurthle cell carcinomas be regarded as distinct entities and that one is not just a subtype of the other.

\section{How common is it?}

In a study from Mount Sinai Hospital in Toronto, Canada, Hurthle cell carcinoma comprised $7 \%$ of all differentiated thyroid cancers. ${ }^{8}$ At the Philippine General Hospital of the University of the Philippines, out of 1084 thyroidectomy specimens over 3 years (2006-2008), there were three cases of Hurthle cell carcinoma $(0.3 \%)$, six Hurthle cell adenomas $(0.6 \%)$, one follicular adenoma with Hurthle cell features $(0.1 \%)$ and two colloid goitres with Hurthle cell changes $(0.2 \%)$.

\section{Are there clinical factors that differentiate benign from malignant Hurthle cell neoplasms?}

Size has been determined to be a distinguishing factor. Hurthle cell carcinomas are significantly larger (mean tumour size $4.0 \mathrm{~cm}$ ) compared with adenomas (mean tumour size $2.4 \mathrm{~cm}$ ). Patient age, sex, history of neck irradiation, bilaterality of tumours and occurrence of concomitant thyroid cancers do not serve to distinguish between benign and malignant Hurthle cell neoplasms. ${ }^{9}$ 


\section{What are the factors that affect disease recurrence and patient survival?}

Tumour size ( $>4 \mathrm{~cm}$ ), extent of vascular invasion ( $>4$ foci), presence of mitosis, a solid or trabecular growth pattern, extrathyroidal extension and presence of lymph node metastases are among the histologic features that predict recurrence. ${ }^{1011}$ Extensive vascular invasion was also found to strongly correlate with worse 5 -year disease-free interval and disease-specific survival. ${ }^{811}$ Of these factors, only a size of $>4 \mathrm{~cm}$ is present in this case being presented. Vascular invasion was not extensive as there was only one focus of such seen on microscopic examination.

\section{How is its clinical behaviour compared with other types of thyroid cancer?}

Hurthle cell carcinoma exhibits a higher rate of distant metastases than papillary and follicular carcinomas. ${ }^{12}$ Despite this, patients with Hurthle cell carcinomas and follicular carcinomas have similar 5 -year survival rates, still much better than the survival rates of anaplastic carcinoma. ${ }^{13-15}$

\section{How is Hurthle cell carcinoma treated?}

Despite the fact that Hurthle cell carcinoma poorly takes up radioactive iodine-131 as demonstrated by radioisotope scans, ${ }^{16}$ treatment with radioactive iodine still prolongs the time without disease progression and improves survival. ${ }^{14}$ Since these tumours also produce thyroglobulin, it can also be used as a marker to monitor treatment response. Thus, it is recommended that these tumours still be treated

\section{Learning points}

- The Hurthle cell, also called oncocyte, is a cell that has undergone morphologic changes in response to cellular stress. They can be found in the thyroid and other organs.

- The morphologic hallmark of Hurthle cells is the presence of an eosinophilic granular cytoplasm that is due to the abundance of mitochondria.

- When these cells proliferate, they can give rise to nodules, both benign and malignant.

- Presented here is a case of Hurthle cell carcinoma of the thyroid (also known as follicular carcinoma, oxyphil type), a rare type of differentiated thyroid carcinoma.

- Treatment of this malignancy is the same for other forms of differentiated thyroid cancers. like other types of differentiated thyroid carcinomas. For this case being presented, there is no evidence of disease after the patient was subjected to total thyroidectomy, radioactive iodine therapy and suppressive levothyroxine treatment.

Acknowledgements We are grateful to the Department of Pathology of the University of the Philippines College of Medicine for the photomicrographs and histological description.

Competing interests None.

Patient consent Obtained.

\section{REFERENCES}

1. Asa SL. My approach to oncocytic tumours of the thyroid. J Clin Pathol 2004;57:225-32.

2. Friedman NB. Cellular involution in the thyroid gland; significance of Hürthle cells in myxedema, exhaustion atrophy, Hashimoto's disease and the reactions to irradiation, thiouracil therapy and subtotal resection. J Clin Endocrinol Metab 1949:9:874-82.

3. Nesland JM, Sobrinho-Simões MA, Holm R, et al. Hürthle-cell lesions of the thyroid: a combined study using transmission electron microscopy, scanning electron microscopy, and immunocytochemistry. Ultrastruct Pathol 1985;8:269-90.

4. Sobrinho-Simões MA, Nesland JM, Holm R, et al. Hürthle cell and mitochondrion-rich papillary carcinomas of the thyroid gland: an ultrastructural and immunocytochemical study. Ultrastruct Pathol 1985;8:131-42.

5. Chen KTK. Fine-needle aspiration cytology of papillary hurthle-cell tumors of the thyroid: a report of three cases. Diagn Cytopathol 1991;7:53-6.

6. Hoos A, Stojadinovic A, Singh B, et al. Clinical significance of molecular expression profiles of Hürthle cell tumors of the thyroid gland analyzed via tissue microarrays. Am J Pathol 2002;160:175-83.

7. Masood S, Auguste LJ, Westerband A, et al. Differential oncogenic expression in thyroid follicular and Hürthle cell carcinomas. Am J Surg 1993;166:366-8.

8. Maxwell EL, Palme CE, Freeman J. Hürthle cell tumors: applying molecular markers to define a new management algorithm. Arch Otolaryngol Head Neck Surg 2006;132:54-8.

9. Chen H, Nicol TL, Zeiger MA, et al. Hürthle cell neoplasms of the thyroid: are there factors predictive of malignancy? Ann Surg 1998;227:542-6.

10. Ghossein RA, Hiltzik DH, Carlson DL, et al. Prognostic factors of recurrence in encapsulated Hurthle cell carcinoma of the thyroid gland: a clinicopathologic study of 50 cases. Cancer 2006;106:1669-76.

11. Stojadinovic A, Hoos A, Ghossein RA et al. Hürthle cell carcinoma: a 60-year experience. Ann Surg Oncol 2002;9:197-203.

12. Shaha AR, Shah JP, Loree TR. Patterns of nodal and distant metastasis based on histologic varieties in differentiated carcinoma of the thyroid. Am J Surg 1996;172:692-4.

13. Bhattacharyya N. Survival and prognosis in Hürthle cell carcinoma of the thyroid gland. Arch Otolaryngol Head Neck Surg 2003;129:207-10.

14. Lopez-Penabad L, Chiu AC, Hoff AO, et al. Prognostic factors in patients with Hürthle cell neoplasms of the thyroid. Cancer 2003;97:1186-94.

15. Sanders LE, Silverman M. Follicular and Hürthle cell carcinoma: predicting outcome and directing therapy. Surgery 1998;124:967-74.

16. Bomanji JB, Gacinovic S, Gaze MN, et al. Recurrent follicular carcinomaoxyphilic cell type (Hürthle cell carcinoma) of the thyroid, imaging with iodine-131 and technetium-99m tetrofosmin before and after radiotherapy. $\mathrm{Br}$ J Radiol 1998;71:87-9. 


\section{BMJ Case Reports}

This pdf has been created automatically from the final edited text and images.

Copyright 2011 BMJ Publishing Group. All rights reserved. For permission to reuse any of this content visit http://group.bmj.com/group/rights-licensing/permissions.

BMJ Case Report Fellows may re-use this article for personal use and teaching without any further permission.

Please cite this article as follows (you will need to access the article online to obtain the date of publication).

Sandoval MAS, Paz-Pacheco E. Hurthle cell carcinoma of the thyroid. BMJ Case Reports 2011;10.1136/bcr.11.2010.3536, date of publication

Become a Fellow of BMJ Case Reports today and you can:

- Submit as many cases as you like

- Enjoy fast sympathetic peer review and rapid publication of accepted articles

- Access all the published articles

- Re-use any of the published material for personal use and teaching without further permission

For information on Institutional Fellowships contact consortiasales@bmjgroup.com

Visit casereports.bmj.com for more articles like this and to become a Fellow 